\title{
SOLUSI PERSAMAAN EMDEN-FOWLER ORDE DUA DENGAN MEMANFAATKAN MATRIKS OPERASIONAL DARI POLINOMIAL BERNSTEIN
}

\author{
Solution of Second Order Emden-Fowler Equations \\ Using Operational Matrix of Bernstein Polynomial \\ Yudhi $^{1}$, Evi Noviani $^{2}$, Sarah Aljona ${ }^{3}$ \\ 1,2,3 Prodi Matematika, Fakultas Matematika dan Ilmu Pengetahuan Alam, Universitas Tanjungpura \\ Jl. Prof. Dr. H. Hadari Nawawi, Pontianak, 78124, Indonesia
}

Corresponding authore-mail: $1 *$ evi_noviani@math.untan.ac.id

\begin{abstract}
Abstrak
Dalam penelitian ini, matriks operasional dari Polinomial Bernstein digunakan untuk mengaproksimasi solusi Persamaan Emden-Fowler orde dua. Untuk mencari solusi Persamaan Emden-Fowler digunakan matriks operasional integral dan matriks operasional diferensial dari Polinomial Bernstein. Karena Persamaan EmdenFowler berorde dua, maka $m \geq 2$ digunakan dalam matriks operasional dari Polinomial Bernstein. Berdasarkan hasil penelitian bahwa solusi Persamaan Emden Fowler dengan $m=3$ diperoleh galat yang lebih kecil daripada dengan $m=2$, baik menggunakan matriks operasional integral maupun matriks operasional diferensial dari Polinomial Bernstein.

Kata Kunci : Matriks operasional dari Polinomial Bernstein, Persamaan Emden-Fowler, matriks operasional integral, matriks operasional diferensial.

Abstract

In this research, the operational matrix of Bernstein Polynomial is used to approximate the solution of second order Emden-Fowler equations. To obtain the solution of the Emden Fowler Equation, we used the integral and differential operational matrix of the Bernstein Polynomial. Because Emden-Fowler Equations have second order, so $m \geq 2$ can used in operational matrix of Bernstein Polynomial. From the solved of research, that the solution of Emden-Fowler's Equation with $m=3$ has a smaller error than with $m=2$ using either an integral operational matrix or an differential operational matrix of Bernstein Polynomial.
\end{abstract}

Keywords: Operational matrix of Bernstein Polynomial, Emden-Fowler Equations, integral operational matrix, differential operational matrix.

Article info:

Submitted: $05^{\text {th }}$ November $2020 \quad$ Accepted: $05^{\text {th }}$ April 2021

How to cite this article:

Y. Yudhi, E. Noviani, and S. Aljona, "SOLUSI PERSAMAAN EMDEN-FOWLER ORDE DUA DENGAN MEMANFAATKAN MATRIKS OPERASIONAL DARI POLINOMIAL BERNSTEIN”, BAREKENG: J. Il. Mat. \& Ter., vol. 15, no. 02, pp. 335-346, Jun. 2021.

This work is licensed under a Creative Commons Attribution-ShareAlike 4.0 International License.

Copyright @ 2021 Yudhi Yudhi, Evi Noviani, Sarah Aljona 


\section{PENDAHULUAN}

Penelitian ini membahas pencarian solusi dari suatu persamaan diferensial biasa nonlinier orde dua. Persamaan diferensial biasa nonlinier orde dua merupakan persamaan diferensial yang nonlinier dan memiliki turunan tertingginya yaitu turunan kedua [1]. Persamaan diferensial biasa nonlinier orde dua yang digunakan dalam penelitian ini adalah Persamaan Emden-Fowler. Suatu solusi persamaan diferensial nonlinier orde dua sulit ditemukan solusi analitiknya, sehingga dapat dicari suatu solusi numeriknya [2]. Menurut Fardinah [2], solusi analitik atau solusi sejati yaitu solusi yang memiliki galat (error) sama dengan nol. Sedangkan solusi numerik yaitu solusi hampiran baik berupa angka ataupun fungsi hampiran terhadap suatu solusi sejati sehingga memiliki galat yang tidak sama dengan nol.

Pencarian solusi numerik dapat diselesaikan dengan menggunakan metode numerik. Metode numerik untuk persamaan diferensial biasa nonlinier orde dua diperoleh solusi yang menghampiri solusi sejati. Oleh karena itu, solusi hampiran tidak selalu tepat sama dengan solusi sejatinya mengakibatkan terdapat selisih di antara solusi hampiran dan solusi sejati yang disebut dengan galat (error) [3]. Metode numerik yang dapat digunakan untuk mencari solusi persamaan diferensial biasa nonlinier orde dua seperti Metode Euler, Metode Heun, Metode Deret Taylor, Metode Runge Kutta, Metode Ekstrapolasi Richardson, dan Metode Banyak Langkah. Terdapat setidaknya empat metode utnuk menyelesaikan Persamaan Emden-Fowler orde dua, yaitu Metode Dekomposisi Adomian [4], matriks operasional dari Polinomial Bernstein [5], matriks operasional dari Polinomial Genocchi [6], dan Metode Kuasilinearisasi Haar Wavelet[7] .

Pada penelitian ini digunakan matriks operasional dari Polinomial Bernstein untuk menyelesaikan Persamaan Emden-Fowler orde dua. Menurut [5], matriks operasional Bernstein dapat mereduksi penghitungan solusi persamaan yang awalnya berbentuk nonlinear menjadi suatu sistem persamaan linear. Matriks operasional dari Polinomial Bernstein pada [5] terdiri dari matriks operasional integral dan matriks operasional diferensial, dan matriks operasional product dari Polinomial Bernstein. Pada penelitian Yousefi dan Behroozifar [5] dibahas pengaplikasian matriks operasional integral dari Polinomial Bernstein untuk mencari solusi Persamaan Bessel dan Persamaan Emden-Fowler orde dua dengan pangkat variabel $y$ yang bernilai 0,1, dan 5. Kemudian untuk matriks operasional diferensial dari Polinomial Bernstein pada [8] digunakan untuk menentukan solusi persamaan diferensial Lane-Emden.

Adapun pada penelitian ini matriks operasional integral dan matriks operasional diferensial dari Polinomial Bernstein digunakan untuk mencari solusi Persamaan Emden-Fowler orde dua yang memiliki pangkat variabel $y$ yaitu $0,1,2$ dengan nilai $m=2$ dan $m=3$. Kemudian dalam proses penyelesaian, menggunakan kondisi dari fungsi aproksimasi terhadap persamaan residual berdasarkan penelitian [8]. Oleh karena itu, berdasarkan [9] yaitu solusi hampiran yang diperoleh dibandingkan terhadap solusi eksak atau kondisi yang seharusnya dari Persamaan Emden-Fowler orde dua untuk memperoleh galat dalam menentukan solusi terbaik.

\section{METODE PENELITIAN}

Bentuk umum Persamaan Emden-Fowler orde dua yaitu :

$$
y^{\prime \prime}(x)+\frac{2}{x} y^{\prime}(x)+x^{r} y^{n}(x)=0, \quad 0 \leq x \leq 1,
$$

dengan kondisi awal

$$
y(0)=1, \quad y^{\prime}(0)=0,
$$

dimana $y^{\prime \prime}(x)$ adalah turunan kedua dari $y$ terhadap $x, y^{\prime}(x)$ adalah turunan pertama dari $y$ terhadap $x$, dan $y^{n}(x)$ adalah fungsi $y$ terhadap $x$ berderajat $n$. Persamaan (1) terlihat bahwa orde tertinggi adalah 2 .

Persamaan Emden-Fowler orde dua pada Persamaan (1) pertama kali perkenalkan oleh Jacob Robert Emden (1862-1940) dan Sir Ralph Howard Fowler (1889-1994) yang dikembangkan dari persamaan diferensial Lane-Emden yang telah dibahas pada [10]. Bentuk Persamaan Emden-Fowler memiliki orde $\geq$ 2 seperti yang dibahas pada [11] untuk orde tiga dan pada [12] untuk orde empat. Selain itu, persamaan Emden-Fowler pada [13]-[15] digunakan untuk memodelkan beberapa fenomena dalam fisika matematis dan astrofisika seperti ledakan termal, struktur bintang, perilaku termal dari awan bola gas, bola gas isothermal dan arus termionik. Adapun untuk memperoleh solusi dari Persamaan (1) maka dapat dicari 
menggunakan matriks operasional integral dan matriks operasional diferensial dari Polinomial Bernstein sebagai berikut.

\subsection{Algoritma Solusi Persamaan Emden-Fowler dengan Menggunakan Matriks Operasional Integral dari Polinomial Bernstein}

Berdasarkan orde dua pada Persamaan (1), maka $m \geq 2$. Kemudian pilih $m$ dari kondisi $m \geq 2$ untuk dicari matriks koefisien dari Polinomial Bernstein yaitu A dan matriks variabel dari Polinomial Bernstein $\mathbf{t}_{\mathbf{m}}(\mathrm{x})$ serta disubstitusikan ke Persamaan (4) untuk memperoleh matriks $\boldsymbol{\phi}(\mathrm{x})$. Lalu dicari matriks $\mathbf{A}^{T}$ dan matriks $\mathbf{A}^{-1}$. Selanjutnya dengan $m \geq 2$, dicari matriks $\boldsymbol{\Lambda}$ dan lanjut mencari matriks $\mathbf{H}$ untuk memperoleh matriks $\mathbf{Q}$. Lalu dicari matriks $\mathbf{Q}^{-1}$. Berikutnya substitusikan matriks $\mathbf{Q}^{-1}$, matriks $\mathbf{A}$ dan $m \geq 2$ untuk memperoleh matriks $\boldsymbol{c}_{\mathrm{m}+1}$ dan $\boldsymbol{c}_{m+1}{ }^{T}$. Berikutnya substitusikan elemen pada entri matriks $\mathbf{A}^{-1}$ dan elemen dari $\boldsymbol{c}_{\mathrm{m}+1}{ }^{T}$ ke rumus matriks $\mathbf{B}$. Kemudian substitusikan matriks $\mathbf{A}, \boldsymbol{\Lambda}$ dan $\mathbf{B}$ ke rumus $\mathbf{P}=\mathbf{A} \mathbf{\Lambda} \mathbf{B}$.

Kemudian diasumsikan bahwa $y^{\prime \prime}(x)=\mathbf{c}^{\mathbf{T}} \boldsymbol{\phi}(\mathrm{x})$. Diintegralkan $y^{\prime \prime}(x)$ untuk mencari $y^{\prime}(x)$ dan $y(x)$. Setelah itu, substitusikan $y^{\prime \prime}(x), y^{\prime}(x)$ dan $y(x)$ ke Persamaan (1) dan dilanjutkan dengan mencari $R_{m}(x)$. Selanjutnya mencari matriks c dengan menggunakan $y(0)=1$ dan $y^{\prime}(0)=0$ berdasarkan kondisi pada Persamaan (2), kemudian disubstitusikan $R_{m}(x)$ dan $B_{k, m}(x), k=0,1, \ldots,(m-2)$ ke persamaan $\int_{0}^{1} R_{m}(x) B_{k, m}(x) d x=0$. Berikutnya hasil matriks $\mathbf{c}$ disubstitusikan ke persamaan $y(x)=\mathbf{c}^{\mathbf{T}} \mathbf{P}^{2} \boldsymbol{\phi}(\mathrm{x})+1$. Lalu cek kelayakan hasil $y(x)$ sebagai solusi terbaik, yaitu mencari galat dengan membandingkan nilai fungsi hasil $y(x)$ terhadap solusi eksak atau persamaan residual terhadap nilai 0 pada sisi kanan Persamaan Emden-Fowler. Dengan demikian, diperoleh $y(x)$ dengan galat terkecil sebagai solusi terbaik Persamaan Emden-Fowler.

\subsection{Algoritma Solusi Persamaan Emden-Fowler dengan Menggunakan Matriks Operasional Diferensial dari Polinomial Bernstein}

Berdasarkan orde dua dari Persamaan (1), maka $m \geq 2$. Pilih $m$ dari kondisi $m \geq 2$ untuk dicari matriks koefisien dari Polinomial Bernstein yaitu $\mathbf{A}$ dan vektor dari variabel Polinomial Bernstein $\mathbf{t}_{\mathbf{m}}(\mathrm{x})$, kemudian disubstitusikan ke Persamaan (4). Berikutnya dicari matriks $\mathbf{A}^{-1}$ dan matriks $\mathbf{F}$ dengan menggunakan nilai $m$. Kemudian disubstitusikan matriks $\mathbf{A}^{-1}$, matriks $\mathbf{F}$ dan matriks $\mathbf{A}$ ke Persamaan (6).

Selanjutnya diasumsikan bahwa $y(x)=\mathbf{c}^{\mathbf{T}} \boldsymbol{\phi}(x)$. Setelah itu, mencari turunan dari $y(x)$ untuk memperoleh $y^{\prime}(x)$ dan $y^{\prime \prime}(x)$. Substitusikan $y^{\prime \prime}(x), y^{\prime}(x)$ dan $y(x)$ ke Persamaan (1) dan dilanjutkan dengan mencari $R_{m}(x)$. Selanjutnya mencari matriks $\mathbf{c}$ dengan menggunakan persamaan $y(0)=1$ dan $y^{\prime}(0)=0$ berdasarkan kondisi pada Persamaan (2), kemudian disubstitusikan $R_{m}(x)$ dan $B_{k, m}(x)$, $k=0,1, \ldots,(m-2)$ ke persamaan $\int_{0}^{1} R_{m}(x) B_{k, m}(x) d x=0$. Berikutnya hasil matriks c disubstitusikan ke $y(x)=\mathbf{c}^{\mathbf{T}} \boldsymbol{\phi}(x)$. Lalu cek kelayakan hasil $y(x)$ sebagai solusi terbaik, yaitu mencari galat dengan membandingkan nilai fungsi hasil $y(x)$ terhadap solusi eksak atau persamaan residual terhadap nilai 0 pada sisi kanan persamaan Emden-Fowler. Dengan demikian, diperoleh $y(x)$ dengan galat terkecil sebagai solusi terbaik persamaan Emden-Fowler.

\subsection{Dekomposisi Matriks Polinomial Bernstein}

Bentuk umum Polinomial Bernstein (PB) yang digunakan pada [16], ditulis sebagai berikut:

$$
B_{k, m}(x)=\sum_{s=0}^{m-k}(-1)^{s}\left(\begin{array}{c}
m \\
k
\end{array}\right)\left(\begin{array}{c}
m-k \\
s
\end{array}\right) x^{k+s},
$$

dengan $\left(\begin{array}{c}\boldsymbol{m} \\ \boldsymbol{k}\end{array}\right)$ adalah kombinasi dari $\boldsymbol{m}$ objek dengan pengambilan sebanyak $\boldsymbol{k}$ objek dan $\boldsymbol{k}=\mathbf{0}, \mathbf{1}, \ldots, \boldsymbol{m}$. Kemudian Polinomial Bernstein dinyatakan dalam matriks Polinomial Bernstein yang disimbolkan dengan $\boldsymbol{\phi}(\boldsymbol{x})$ :

$$
\phi(x)=\mathbf{A t}_{\mathbf{m}}(x),
$$

dengan matriks $\mathbf{A}$ adalah matriks koefisien dari Polinomial Bernstein dan $\mathbf{t}_{\mathbf{m}}(x)$ adalah vektor dari variabel Polinomial Bernstein. Matriks $\mathbf{A}$ dan $\mathbf{t}_{\mathbf{m}}(x)$ dinyatakan sebagai berikut: 


$$
\mathbf{A}=\left[\begin{array}{cccc}
(-1)^{0}\left(\begin{array}{c}
m \\
0
\end{array}\right)\left(\begin{array}{c}
m-0 \\
0
\end{array}\right) & (-1)^{1}\left(\begin{array}{c}
m \\
0
\end{array}\right)\left(\begin{array}{c}
m-0 \\
1
\end{array}\right) & \cdots & (-1)^{m-0}\left(\begin{array}{c}
m \\
0
\end{array}\right)\left(\begin{array}{c}
m-0 \\
m-0
\end{array}\right) \\
0 & (-1)^{0}\left(\begin{array}{c}
m \\
1
\end{array}\right)\left(\begin{array}{c}
m-1 \\
0
\end{array}\right) & \cdots & (-1)^{m-1}\left(\begin{array}{c}
m \\
1
\end{array}\right)\left(\begin{array}{c}
m-1 \\
m-1
\end{array}\right) \\
\vdots & \vdots & \ddots & \vdots \\
0 & 0 & \cdots & (-1)^{m-k}\left(\begin{array}{c}
m \\
k
\end{array}\right)\left(\begin{array}{c}
m-m \\
m-m
\end{array}\right)
\end{array}\right], \mathbf{t}_{\mathbf{m}}(x)=\left[\begin{array}{c}
1 \\
x \\
\vdots \\
x^{m}
\end{array}\right] .
$$

Kemudian pada matriks operasional dari Polinomial Bernstein terdapat dua matriks operasional sebagai berikut

\section{Matriks Operasional Integral dari Polinomial Bernstein}

Matriks operasional integral dinyatakan dengan matriks $\mathbf{P}$ yang berukuran $(m+1) \times(m+1)$ dan memenuhi:

$$
\int_{0}^{x} \boldsymbol{\phi}(\mathbf{t}) d t \simeq \mathbf{P} \boldsymbol{\phi}(\mathbf{x}), \quad 0 \leq x \leq 1 .
$$

Matriks $\mathbf{P}$ dinyatakan dengan

$$
\mathbf{P}=\mathbf{A} \mathbf{\Lambda} \mathbf{B}
$$

Adapun $\boldsymbol{\Lambda}$ sebagai matriks koefisen dengan elemen $\Lambda_{i i}=\frac{1}{i}, i=1, \ldots, m+1$ dan $\mathbf{B}$ merupakan matriks berukuran $(m+1) \times(m+1)$ yang dinyatakan sebagai berikut.

$$
\boldsymbol{\Lambda}=\left[\begin{array}{cccc}
1 & 0 & \cdots & 0 \\
0 & \frac{1}{2} & \cdots & 0 \\
\vdots & \vdots & & \vdots \\
0 & 0 & \cdots & \frac{1}{m+1}
\end{array}\right] \quad \text { dan } \quad \mathbf{B}=\left[\begin{array}{c}
\mathrm{A}_{2}^{-1} \\
\vdots \\
\mathrm{A}_{m+1}^{-1} \\
c_{m+1}^{T}
\end{array}\right]
$$

Adapun elemen $\mathrm{A}_{2}^{-1}, \mathrm{~A}_{3}^{-1}, \ldots, \mathrm{A}_{m+1}^{-1}$ merupakan sub baris dari $\mathbf{A}^{-1}$ dan untuk elemen baris $c_{m+1}^{T}$ diperoleh menggunakan persamaan sebagai berikut.

$$
\boldsymbol{c}_{\boldsymbol{m}+\mathbf{1}}=\left(\mathbf{Q}^{-1}\right)^{\boldsymbol{T}} \mathbf{A}\left(\left[\begin{array}{c}
\frac{1}{m+2} \\
\frac{1}{m+3} \\
\vdots \\
\frac{1}{2 m+2}
\end{array}\right]\right)
$$

dengan $\mathbf{Q}$ merupakan matriks bujur sangkar yang dinyatakan sebagai berikut.

$$
\mathbf{Q}=\mathbf{A H A}^{\mathbf{T}}, \quad \mathbf{H}=\left[\begin{array}{cccc}
1 & \frac{1}{2} & \cdots & \frac{1}{m+1} \\
\frac{1}{2} & \frac{1}{3} & \cdots & \frac{1}{m+2} \\
\vdots & \vdots & & \vdots \\
\frac{1}{m+1} & \frac{1}{m+2} & \cdots & \frac{1}{2 m+1}
\end{array}\right]
$$

2. Matriks Operasional Diferensial dari Polinomial Bernstein

Matriks operasional diferensial dinyatakan dengan matriks D yaitu matriks yang berukuran $(m+1) \times(m+1)$, dan memenuhi:

$$
\frac{d}{d x} \boldsymbol{\phi}(\boldsymbol{x})=\mathbf{D} \boldsymbol{\phi}(\boldsymbol{x}), \quad 0 \leq x \leq 1 .
$$

Matriks D dinyatakan sebagai berikut.

$$
\mathbf{D}=\mathbf{A F A}^{-1}
$$


dengan $\mathbf{F}$ merupakan matriks yang berukuran $(m+1) \times(m+1)$ yang dinyatakan

$$
\mathbf{F}=\left[\begin{array}{ccccc}
0 & 0 & \cdots & 0 & 0 \\
1 & 0 & \cdots & 0 & 0 \\
0 & 2 & \cdots & 0 & 0 \\
\vdots & \vdots & \ddots & \vdots & \vdots \\
0 & 0 & \cdots & m & 0
\end{array}\right] .
$$

Dengan menggunakan kedua matriks operasional dari Polinomial Bernstein, maka dapat diaplikasikan untuk mencari solusi persamaan diferensial. Solusi persamaan diferensial tersebut merupakan suatu fungsi aproksimasi dari solusinya, dengan bentuk:

$$
y_{0}=c^{T} \phi(x), \quad c^{T}=\left[c_{0}, c_{1}, \ldots, c_{m}\right] .
$$

Residual dinyatakan sebagai $\boldsymbol{R}_{\boldsymbol{m}}(\boldsymbol{x})$ ditulis:

$$
R_{m}(x) \approx f-y_{0}
$$

Oleh karena itu, berdasarkan [6] yaitu dengan menggunakan $\boldsymbol{R}_{\boldsymbol{m}}(\boldsymbol{x})$ dan Polinomial Bernstein $\boldsymbol{B}_{\boldsymbol{k}, \boldsymbol{m}}$ maka memenuhi keadaan berikut.

$$
\left\langle R_{m}(x), B_{k, m}\right\rangle=\int_{0}^{1} R_{m}(x) B_{k, m} d t=0, \quad k=0,1, \ldots m-2
$$

Persamaan (7) berlaku untuk masing-masing nilai $\boldsymbol{k}$, sehingga memungkinkan lebih dari satu persamaan yang dihasilkan untuk setiap nilai $\boldsymbol{m}$. Selanjutnya, merujuk pada [5], jika persamaan (7) terpenuhi maka dapat kita tentukan vektor koefisien $\boldsymbol{c}^{\boldsymbol{T}}$ yang akan menentukan solusi aproksimasi $\boldsymbol{y}_{\mathbf{0}}$.

\section{HASIL DAN PEMBAHASAN}

Pada bab ini, dibahas pengaplikasian matriks operasional dari Polinomial Bernstein untuk mencari solusi Persamaan Emden Fowler orde dua yang terdapat pada Persamaan (1) dengan kondisi awal pada Persamaan (2). Penentuan solusi Persamaan Emden Fowler dibahas menggunakan matriks operasional integral dan matriks operasional diferensial dari Polinomial Bernstein. Adapun dalam penelitian ini, digunakan tiga kasus dari Persamaan Emden-Fowler orde dua yaitu untuk $r=0, n=0$, untuk $r=0, n=1$ dan untuk $r=0, n=2$ dengan menggunakan $m=2$ dan $m=3$.

\subsection{Solusi Persamaan Emden-Fowler dengan Menggunakan Matriks Operasional Integral dari Polinomial Bernstein}

Subbab ini membahas pencarian solusi Persamaan Emden Fowler orde dua dengan menggunakan matriks operasional integral dari Polinomial Bernstein sebagai berikut:

Kasus 1. Persamaan Emden-Fowler untuk $r=0, n=0$ dituliskan

dengan kondisi awal

$$
y^{\prime \prime}(x)+\frac{2}{x} y^{\prime}(x)+1=0, \quad 0 \leq x \leq 1,
$$

$$
y(0)=1, \quad y^{\prime}(0)=0 .
$$

Orde tertinggi di Persamaan (8) adalah dua, maka diperoleh $m \geq 2$. Dipilih $m=2$ untuk disubstitusikan ke Persamaan (4) dan Persamaan (6) sedemikian sehingga diperoleh sebagai berikut.

$$
\phi(x)=\left[\begin{array}{c}
1-2 x+x^{2} \\
2 x-2 x^{2} \\
x^{2}
\end{array}\right], \quad \mathbf{P}=\left[\begin{array}{ccc}
\frac{1}{60} & \frac{5}{12} & \frac{19}{60} \\
-\frac{1}{30} & \frac{1}{6} & \frac{11}{30} \\
\frac{1}{60} & -\frac{1}{12} & \frac{19}{60}
\end{array}\right]
$$

Diasumsikan bahwa 
maka untuk $a=2$ dan $m \geq 2$ diperoleh

$$
y^{(a)}(x)=\mathbf{c}^{\mathbf{T}} \boldsymbol{\phi}(x)
$$

$$
\begin{aligned}
y^{\prime \prime}(x) & =\mathbf{c}^{\mathrm{T}} \boldsymbol{\phi}(x), \\
\mathbf{c} & =\left[\begin{array}{l}
c_{0} \\
c_{1} \\
c_{2}
\end{array}\right] .
\end{aligned}
$$

Berikutnya diintegralkan Persamaan (10) sedemikian sehingga diperoleh

$$
y^{\prime}(x)=\mathbf{c}^{\mathbf{T}} \mathbf{P} \boldsymbol{\phi}(x), \quad y(x)=\mathbf{c}^{\mathbf{T}} \mathbf{P}^{2} \boldsymbol{\phi}(x)+1 .
$$

Kemudian mencari persamaan residual sedemikian sehingga diperoleh

$$
R_{m}(x)=x \mathbf{c}^{\mathbf{T}} \boldsymbol{\phi}(x)+2 \mathbf{c}^{\mathbf{T}} \mathbf{P} \boldsymbol{\phi}(x)+x .
$$

Adapun berdasarkan kondisi awal pada Persamaan (2) dan substitusikan Persamaan (9) dan (11) ke Persamaan (12) diperoleh hasil

$$
c_{2}=c_{0}, \quad c_{1}=c_{0} .
$$

Selanjutnya substitusikan Persamaan (13), Persamaan (9), Persamaan (11) dan Persamaan (14) ke Persamaan (7) sedemikian sehingga diperoleh

$$
c_{0}=-\frac{1}{3}
$$

Setelah itu, disubstisikan Persamaan (14) dan Persamaan (15) ke Persamaan (11) maka diperoleh

$$
\boldsymbol{c}=\left[\begin{array}{r}
-\frac{1}{3} \\
-\frac{1}{3} \\
-\frac{1}{3}
\end{array}\right] .
$$

Kemudian disubstitusikan Persamaan (10) dan Persamaan (17) ke Persamaan (13) diperoleh

$$
y(x)=1-\frac{1}{6} x^{2} .
$$

Selain itu Persamaan (17) merupakan solusi terbaik karena dalam [6] menunjukkan bahwa Persamaan (17) sama dengan solusi eksak dari persamaan Emden-Fowler untuk $r=0, n=0$.

Kasus 2. Persamaan Emden-Fowler $r=0, n=1$ sehingga diperoleh

dengan kondisi awal

$$
y^{\prime \prime}(x)+\frac{2}{x} y^{\prime}(x)+y(x)=0, \quad 0 \leq x \leq 1,
$$

$$
y(0)=1, \quad y^{\prime}(0)=0 .
$$

Karena kasus 2 memiliki kondisi awal yang sama dengan kasus 1 maka berdasarkan Persamaan (13) diperoleh $c_{2}=c_{0}$ dan $c_{1}=c_{0}$. Kemudian mencari persamaan residual diperoleh

$$
R_{m}(x)=x \mathbf{c}^{\mathbf{T}} \boldsymbol{\phi}(x)+2 \mathbf{c}^{\mathbf{T}} \mathbf{P} \boldsymbol{\phi}(x)+x \mathbf{c}^{\mathbf{T}} \mathbf{P}^{2} \boldsymbol{\phi}(x)+x .
$$

Selanjutnya substitusikan Persamaan (19), Persamaan (9), Persamaan (11) dan Persamaan (14) ke Persamaan (7) sedemikian sehingga diperoleh

$$
c_{0}=-0,3225806 \text {. }
$$

Substitusi Persamaan (14) dan Persamaan (20) maka Persamaan (11) diperoleh

$$
\boldsymbol{c}=\left[\begin{array}{l}
-0,3225806 \\
-0,3225806 \\
-0,3225806
\end{array}\right] \text {. }
$$


Lalu substitusikan Persamaan (9) dan Persamaan (21) ke Persamaan (12) sehingga diperoleh

$$
y(x)=1-0,1612903 x^{2} .
$$

Berdasarkan [6], persamaan Emden-Fowler dengan $r=0, n=1$ memiliki solusi eksak yaitu :

$$
y(x)=\frac{\sin (x)}{x} \text {. }
$$

Oleh karena itu dapat diperoleh galat dengan membandingkan nlai fungsi dari hasil substitusi nilai $x=(0,1 ; 0,2 ; \ldots ; 1)$ ke Persamaan $(22)$ dan Persamaan $(23)$ yang disajikan pada Tabel 1 . Adapun untuk memperoleh galat yang lebih kecil, dapat digunakan ukuran matriks yang lebih besar dengan $m \geq 2$ yaitu dipilih $m=3$ sehingga diperoleh

$$
y(x)=1-1,951563910 \cdot\left(10^{-18}\right) x-0,17044985555 \mathrm{x}^{2}+0,0115559224 \mathrm{x}^{3} .
$$

Kemudian substitusikan nilai $x=(0,1 ; 0,2 ; \ldots ; 1)$ ke Persamaan (24) dan Persamaan (23). Selanjutnya untuk memperoleh galat, hasil nilai fungsi Persamaan (24) dibandingkan dengan nilai fungsi Persamaan (23) yang disajikan dalam Tabel 1 sebagai berikut:

Tabel 1. Hasil galat solusi Persamaan Emden-Fowler $r=0, n=1$

\begin{tabular}{cccccc}
\hline $\boldsymbol{x}$ & Eksak & PB $\boldsymbol{m}=\mathbf{2}$ & Galat $\boldsymbol{m}=\mathbf{2}$ & $\mathbf{P B} \boldsymbol{m}=\mathbf{3}$ & Galat $\boldsymbol{m}=\mathbf{3}$ \\
\hline 0,1 & 0,998334166 & 0,998387097 & $5,29305 \mathrm{E}-05$ & 0,99830706 & $2,7109 \mathrm{E}-05$ \\
\hline 0,2 & 0,993346654 & 0,993548388 & 0,000201734 & 0,99327445 & $7,2201 \mathrm{E}-05$ \\
\hline 0,3 & 0,985067356 & 0,985483873 & 0,000416517 & 0,98497152 & $9,5833 \mathrm{E}-05$ \\
\hline 0,4 & 0,973545856 & 0,974193552 & 0,000647696 & 0,9734676 & $7,8254 \mathrm{E}-05$ \\
\hline 0,5 & 0,958851077 & 0,959677425 & 0,000826348 & 0,95883203 & $1,9051 \mathrm{E}-05$ \\
\hline 0,6 & 0,941070789 & 0,941935492 & 0,000864703 & 0,94113413 & $6,3342 \mathrm{E}-05$ \\
\hline 0,7 & 0,920310982 & 0,920967753 & 0,000656771 & 0,92044325 & $1,3227 \mathrm{E}-04$ \\
\hline 0,8 & 0,896695114 & 0,896774208 & $7,90944 \mathrm{E}-05$ & 0,89682872 & $1,3361 \mathrm{E}-04$ \\
\hline 0,9 & 0,870363233 & 0,869354857 & 0,001008376 & 0,87035988 & $3,3484 \mathrm{E}-06$ \\
\hline 1 & 0,841470985 & 0,8387097 & 0,002761285 & 0,84110607 & $3,6492 \mathrm{E}-04$ \\
\hline
\end{tabular}

Selain itu, hasil pada Tabel 1 dapat disajikan dalam bentuk grafik pada Gambar 1 sebagai berikut.

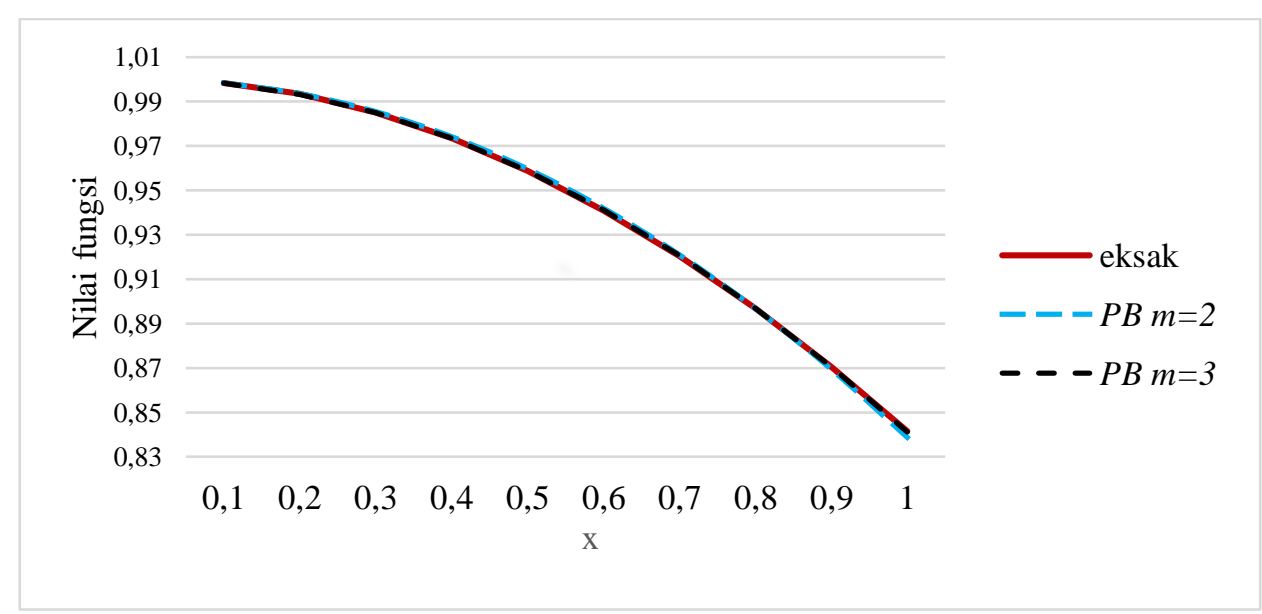

Gambar 1. Grafik solusi Persamaan Emden-Fowler $r=0, n=1$

Berdasarkan Tabel 1 dan Gambar 1, diperoleh solusi dengan galat terkecil yang mendekati solusi eksak yaitu solusi dengan menggunakan $m=3$ yang terdapat pada Persamaan (24).

Kasus 3. Persamaan Emden-Fowler $r=0, n=2$ sehingga diperoleh 


$$
y^{\prime \prime}(x)+\frac{2}{x} y^{\prime}(x)+y^{2}(x)=0, \quad 0 \leq x \leq 1,
$$

dengan kondisi awal

$$
y(0)=1, \quad y^{\prime}(0)=0 .
$$

Karena kasus 1,2 dan 3 memiliki kondisi awal yang sama, maka berdasarkan Persamaan (14) diperoleh $c_{2}=c_{0}$ dan $c_{1}=c_{0}$. Kemudian mencari persamaan residual sehingga diperoleh

$$
R_{m}(x)=x \mathbf{c}^{\mathbf{T}} \boldsymbol{\phi}(\mathrm{x})+2 \mathbf{c}^{\mathbf{T}} \mathbf{P} \boldsymbol{\phi}(\mathrm{x})+x\left(\mathbf{c}^{\mathbf{T}} \mathbf{P}^{2} \boldsymbol{\phi}(\mathrm{x})\right)\left(\mathbf{c}^{\mathbf{T}} \mathbf{P}^{2} \boldsymbol{\phi}(\mathrm{x})\right)+2 x \mathbf{c}^{\mathbf{T}} \mathbf{P}^{2} \boldsymbol{\phi}(\mathrm{x})+x .
$$

Selanjutnya substitusikan Persamaan (26), Persamaan (9), Persamaan (11) dan Persamaan (14) ke Persamaan (7) sedemikian sehingga diperoleh

$$
c_{0}=-0,31306866 \text {. }
$$

Substitusikan Persamaan (14) dan (27) ke Persamaan (11) menjadi

$$
\mathbf{c}=\left[\begin{array}{l}
-0,31306866 \\
-0,31306866 \\
-0,31306866
\end{array}\right]
$$

Lalu substitusikan Persamaan (14) dan Persamaan (28) ke Persamaan (12) sehingga diperoleh solusi sebagai berikut.

$$
y(x)=1-0,156523433 x^{2}
$$

Karena Persamaan (25) tidak memiliki solusi eksak, maka Persamaan (29) dapat disubstitusikan ke Persamaan (25) yaitu sebagai berikut.

$$
y^{\prime \prime}(x)+\frac{2}{x} y^{\prime}(x)+y^{2}(x)=0,060859402-0,313046866 x^{2}+0,024499585 x^{4} .
$$

Adapun dengan disubstitusikan $x=(0,1 ; 0,2 ; \ldots ; 1)$ ke ruas kanan Persamaan (30) dan dibandingkan dengan nilai 0 pada ruas kanan Persamaan (25) diperoleh galat yang disajikan pada Tabel 2. Karena $m \geq 2$ maka dapat dipilih untuk $m=3$ yaitu :

$$
y(x)=1+(8,4567769454)\left(10^{-18}\right) x-0,1734170935 x^{2}+0,02148937175 x^{3} .
$$

Berikutnya Persamaan (31) dapat disubstitusikan ke Persamaan (25) sehingga diperoleh

$$
\begin{aligned}
y^{\prime \prime}(x)+\frac{2}{x} y^{\prime}(x)+y^{2}= & -0,0405025950+0,2578724820 x-0,3468341975 x^{2}+ \\
& 0,042978747 x^{3}+0,03007349014 x^{4}-0,007453249613 x^{5}+ \\
& 0,0004617931734 x^{6}+\frac{(2,602085214)\left(10^{-18}\right)}{x} .
\end{aligned}
$$

Selanjutnya substitusikan $x=(0,1 ; 0,2 ; \ldots ; 1)$ ke Persamaan (32) dan dibandingkan dengan 0 yaitu hasil sisi kanan dari Persamaan (25) untuk memperoleh galat yang disajikan pada Tabel 2.

Tabel 2. Galat pembanding ruas kanan Persamaan Emden-Fowler dengan nilai fungsi dari hasil solusi menggunakan matriks operasional integral dari Polinomial Bernstein

\begin{tabular}{cccccc}
\hline $\boldsymbol{x}$ & $\begin{array}{c}\text { Ruas Sisi Kanan } \\
\text { Persamaan } \\
\text { Emden-Fowler }\end{array}$ & $\boldsymbol{m}=\mathbf{2}$ & Galat $\boldsymbol{m}=\mathbf{2}$ & $\boldsymbol{m}=\mathbf{3}$ & Galat $\boldsymbol{m}=\mathbf{3}$ \\
\hline 0,1 & 0 & 0,057974 & 0,057974 & $-0,018138$ & 0,018138 \\
\hline 0,2 & 0 & 0,049318 & 0,049318 & $-0,002412$ & 0,002412 \\
\hline 0,3 & 0 & 0,03489 & 0,03489 & 0,00703 & 0,00703 \\
\hline 0,4 & 0 & 0,014692 & 0,014692 & 0,010599 & 0,010599 \\
\hline 0,5 & 0 & $-0,011277$ & 0,011277 & 0,008751 & 0,008751 \\
\hline 0,6 & 0 & $-0,043018$ & 0,043018 & 0,001984 & 0,001984 \\
\hline 0,7 & 0 & $-0,080529$ & 0,080529 & $-0,009177$ & 0,009177 \\
\hline $\boldsymbol{x}$ & Ruas Sisi Kanan & $\boldsymbol{m}=\mathbf{2}$ & Galat $\boldsymbol{m}=\mathbf{2}$ & $\boldsymbol{m}=\mathbf{3}$ & Galat $\boldsymbol{m}=\mathbf{3}$ \\
\hline & & & & & \\
\hline
\end{tabular}




\begin{tabular}{cccccc}
\hline \multicolumn{7}{c}{$\begin{array}{c}\text { Persamaan } \\
\text { Emden-Fowler }\end{array}$} & & & & \\
\hline 0,8 & 0 & $-0,123811$ & 0,123811 & $-0,024176$ & 0,024176 \\
\hline 0,9 & 0 & $-0,172864$ & 0,172864 & $-0,042446$ & 0,042446 \\
\hline 1 & 0 & $-0,227688$ & 0,227688 & $-0,063404$ & 0,063404 \\
\hline
\end{tabular}

Berdasarkan Tabel 2, diperoleh bahwa galat pada $m=3$ lebih kecil dari $m=2$. Dengan demikian solusi Persamaan Emden-Fowler $r=0, n=2$ berada pada Persamaan (31).

\subsection{Solusi Persamaan Emden-Fowler dengan Menggunakan Matriks Operasional Diferensial dari Polinomial Bernstein}

Subbab ini membahas pencarian solusi persamaan diferensial Emden Fowler orde dua dengan menggunakan matriks operasional diferensial dari Polinomial Bernstein yang dijabarkan dengan tiga kasus berbeda sebagai berikut.

Kasus 1. Persamaan Emden-Fowler $r=0, n=0$ yang terdapat pada Persamaan (8) dengan kondisi awal pada Persamaan (2). Kemudian dengan menggunakan orde tertinggi $a=2$, maka diperoleh $m \geq 2$. Dipilih $m=2$ untuk disubstitusikan ke Persamaan (4) dan Persamaan (6) sedemikian sehingga diperoleh

$$
\boldsymbol{\phi}(\mathbf{x})=\left[\begin{array}{c}
1-2 x+x^{2} \\
2 x-2 x^{2} \\
x^{2}
\end{array}\right], \mathbf{D}=\left[\begin{array}{ccc}
-2 & -1 & 0 \\
2 & 0 & -2 \\
0 & 1 & 2
\end{array}\right]
$$

Diasumsikan bahwa

$$
y(x)=\mathbf{c}^{\mathbf{T}} \boldsymbol{\phi}(\mathbf{x}) .
$$

Adapun diperoleh turunan dari Persamaan (34) yaitu :

$$
y^{\prime}(x)=\mathbf{c}^{\mathbf{T}} \mathbf{D} \boldsymbol{\phi}(\mathbf{x}), \quad y^{\prime \prime}(x)=\mathbf{c}^{\mathbf{T}} \mathbf{D}^{2} \boldsymbol{\phi}(\mathbf{x}) .
$$

Kemudian dicari persamaan residual sedemikian sehingga diperoleh

$$
R_{m}(x)=x \mathbf{c}^{\mathbf{T}} \mathbf{D}^{2} \boldsymbol{\phi}(\mathbf{x})+2 \mathbf{c}^{\mathbf{T}} \mathbf{D} \boldsymbol{\phi}(\mathbf{x})+x .
$$

Kemudian berdasarkan kondisi awal pada Persamaan (2), dengan disubstitusikan Persamaan (11) dan Persamaan (33) ke Persamaan (34) dan Persamaan (35) sehingga diperoleh

$$
c_{0}=1, \quad c_{1}=1 .
$$

Selanjutnya substitusikan Persamaan (36), Persamaan (11), Persamaan (33) dan Persamaan (37) ke Persamaan (7) sedemikian sehingga diperoleh

$$
c_{2}=\frac{5}{6}
$$

Adapun dengan disubstitusikan Persamaan (37) dan Persamaan (38) ke Persamaan (11) maka diperoleh

$$
\mathbf{c}=\left[\begin{array}{l}
1 \\
1 \\
\frac{5}{6}
\end{array}\right]
$$

Substitusikan Persamaan (33) dan Persamaan (39) ke Persamaan (34) sehingga diperoleh hasil yang sama dengan Persamaan (17). Selain itu diketahui pada [1], Persamaan (17) juga merupakan solusi eksak dari persamaan Emden-Fowler $r=0, n=0$.

Kasus 2. Persamaan Emden-Fowler $r=0, n=1$ yang terdapat pada Persamaan (18) dengan kondisi awal pada Persamaan (2).

Karena kasus 1 dan 2 memiliki kondisi awal yang sama, maka berdasarkan Persamaan (37) diperoleh $c_{0}=$ 1 dan $c_{1}=1$. Selanjutnya dicari persamaan residual sedemikian sehingga diperoleh

$$
R_{m}(x)=x \mathbf{c}^{\mathbf{T}} \mathbf{D}^{2} \boldsymbol{\phi}(\mathbf{x})+2 \mathbf{c}^{\mathbf{T}} \mathbf{D} \boldsymbol{\phi}(\mathbf{x})+x \mathbf{c}^{\mathbf{T}} \boldsymbol{\phi}(\mathbf{x}) .
$$


Selanjutnya substitusikan Persamaan (40), Persamaan (11), Persamaan (33) dan Persamaan (37) ke Persamaan (7) sedemikian sehingga diperoleh

$$
c_{2}=0,8387097
$$

Dengan demikian, disubstitusikan Persamaan (37) dan Persamaan (41) ke Persamaan (11) sehingga menjadi

$$
\mathbf{c}=\left[\begin{array}{c}
1 \\
1 \\
0,8387097
\end{array}\right] .
$$

Oleh karena itu, disubtitusikan Persamaan (33) dan Persamaan (42) ke Persamaan (34) sedemikian sehingga diperoleh

$$
y(x)=1-0,1612903 x^{2} .
$$

Selanjutnya bandingkan nilai fungsi dari hasil substitusi $x=(0,1 ; 0,2 ; \ldots ; 1)$ ke Persamaan $(43)$ dan Persamaan (23) untuk memperoleh galat yang disajikan pada Tabel 3. Kemudian karena $m \geq 2$, untuk memperoleh galat lebih kecil dapat dipilih $m=3$ sedemikian sehingga diperoleh

$$
y(x)=1-0,170449856 x^{2}+0,011555923 x^{3} .
$$

Kemudian diperoleh galat dengan membandingkan nilai fungsi dari hasil substitusi $x=(0,1 ; 0,2 ; \ldots ; 1)$ ke Persamaan (44) dan Persamaan (23) yang disajikan pada Tabel 3 dan Gambar 2 sebagai berikut:

Tabel 3. Hasil galat solusi Persamaan Emden-Fowler $r=0, n=1$

\begin{tabular}{cccccc}
\hline$x$ & Eksak & PB $m=2$ & Galat $m=2$ & PB $m=3$ & Galat $m=3$ \\
\hline 0,1 & 0,998334166 & 0,998387097 & $5,29305 \mathrm{E}-05$ & 0,99830706 & $2,7109 \mathrm{E}-05$ \\
\hline 0,2 & 0,993346654 & 0,993548388 & 0,000201734 & 0,99327445 & $7,2201 \mathrm{E}-05$ \\
\hline 0,3 & 0,985067356 & 0,985483873 & 0,000416517 & 0,98497152 & $9,5833 \mathrm{E}-05$ \\
\hline 0,4 & 0,973545856 & 0,974193552 & 0,000647696 & 0,9734676 & $7,8254 \mathrm{E}-05$ \\
\hline 0,5 & 0,958851077 & 0,959677425 & 0,000826348 & 0,95883203 & $1,9051 \mathrm{E}-05$ \\
\hline 0,6 & 0,941070789 & 0,941935492 & 0,000864703 & 0,94113413 & $6,3342 \mathrm{E}-05$ \\
\hline 0,7 & 0,920310982 & 0,920967753 & 0,000656771 & 0,92044325 & $1,3227 \mathrm{E}-04$ \\
\hline 0,8 & 0,896695114 & 0,896774208 & $7,90944 \mathrm{E}-05$ & 0,89682872 & $1,3361 \mathrm{E}-04$ \\
\hline 0,9 & 0,870363233 & 0,869354857 & 0,001008376 & 0,87035988 & $3,3484 \mathrm{E}-06$ \\
\hline 1 & 0,841470985 & 0,8387097 & 0,002761285 & 0,84110607 & $3,6492 \mathrm{E}-04$ \\
\hline
\end{tabular}

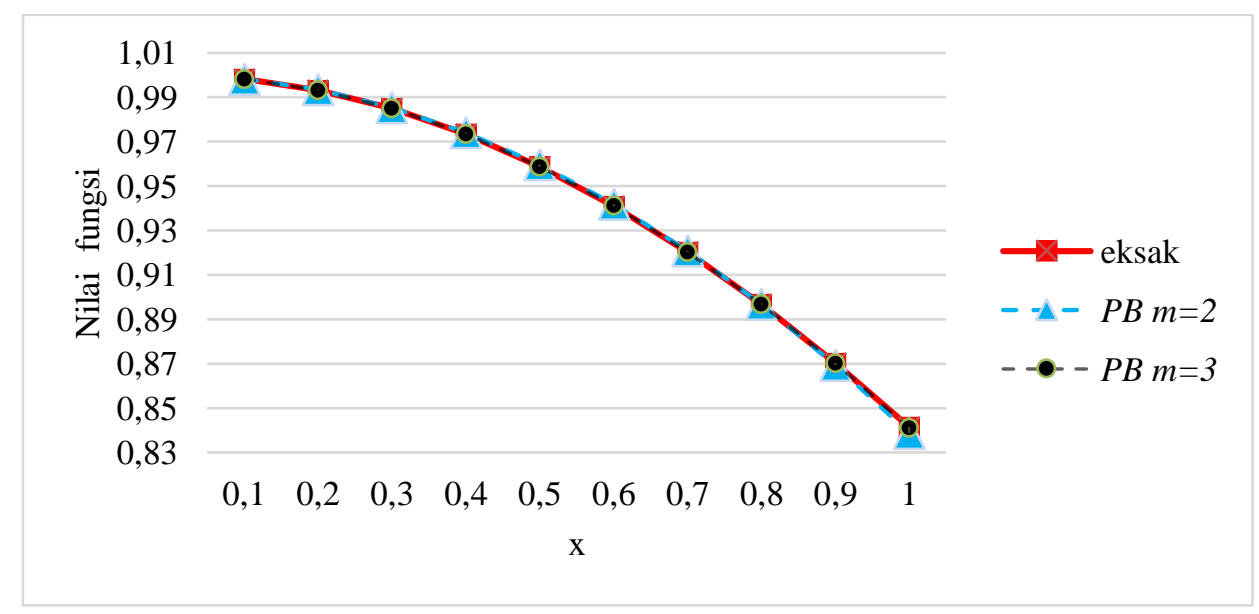

Gambar 2. Grafik solusi Persamaan Emden-Fowler $r=0, n=1$

Dengan demikian, berdasarkan Tabel 3 dan Gambar 2 galat yang lebih kecil dan mendekati solusi eksak berada pada Persamaan (44).

Kasus 3. Persamaan Emden-Fowler $r=0, n=2$ yang terdapat pada Persamaan (26) dengan kondisi awal pada Persamaan (2). 
Karena kasus 1, 2 dan 3, memiliki kondisi awal yang sama maka berdasarkan Persamaan (37) diperoleh $c_{0}=1$ dan $c_{1}=1$. Kemudian dicari persamaan residual sedemikian sehingga diperoleh

$$
R_{m}(x)=x \mathbf{c}^{\mathbf{T}} \mathbf{D}^{2} \boldsymbol{\phi}(\mathbf{x})+2 \mathbf{c}^{\mathbf{T}} \mathbf{D} \boldsymbol{\phi}(\mathbf{x})+x \mathbf{c}^{\mathbf{T}} \boldsymbol{\phi}(\mathbf{x}) \mathbf{c}^{\mathbf{T}} \boldsymbol{\phi}(\mathbf{x}) .
$$

Selanjutnya substitusikan Persamaan (45) Persamaan (11), Persamaan (33) dan Persamaan (37) ke Persamaan ke Persamaan (7) sedemikian sehingga diperoleh

$$
c_{2}=0,8387097 \text {. }
$$

Lalu substitusikan Persamaan (37) dan Persamaan (46) ke Persamaan (11) diperoleh

$$
\mathbf{c}=\left[\begin{array}{c}
1 \\
1 \\
0,843476567
\end{array}\right] .
$$

Oleh karena itu, disubstitusi Persamaan (33) dan Persamaan (47) ke Persamaan (34) sedemikian sehingga diperoleh

$$
y(x)=1-0,156523433 x^{2} .
$$

Kemudian untuk membuktikan Persamaan (48) adalah solusi terbaik maka disubstitusikan Persamaan (48) ke Persamaan (25) sedemikian sehingga diperoleh

$$
y^{\prime \prime}(x)+\frac{2}{x} y^{\prime}(x)+y^{2}=0,060859402-0,313046866 x^{2}+0,024499585 x^{4} .
$$

Adapun dengan disubstitusikan $x=(0,1 ; 0,2 ; \ldots ; 1)$ ke ruas kanan Persamaan (49) dan dibandingkan dengan nilai 0 pada Persamaan (25) sehingga diperoleh galat yang disajikan pada Tabel 4 . Karena $m \geq 2$ maka untuk

memperoleh galat yang lebih kecil dapat dipilih untuk $m=3$ sedemikian sehingga diperoleh

$$
y(x)=1-0,173417099 x^{2}+0,021489374 x^{3} .
$$

Berikutnya Persamaan (50) disubstitusikan ke Persaman (25) sehingga diperoleh

$$
\begin{aligned}
y^{\prime \prime}(x)+\frac{2}{x} y^{\prime}(x)+y^{2}= & -0,040502594+0,257872488 x+0,346834198 x^{2}+ \\
& 0,042978748 x^{3}+0,030073490 x^{4}- \\
& 0,00745325 x^{5}+0,0004617932 x^{6} .
\end{aligned}
$$

Selanjutnya substitusikan $x=(0,1 ; 0,2 ; \ldots ; 1)$ ke Persamaan $(51)$ dan dibandingkan dengan nilai 0 pada ruas kanan dari Persamaan (25) untuk memperoleh galat yang disajikan pada Tabel 4.

Tabel 4. Galat pembanding sisi kanan Persamaan Emden-Fowler dengan hasil menggunakan matriks operasional diferensial dari Polinomial Bernstein

\begin{tabular}{cccccc}
\hline $\boldsymbol{x}$ & $\begin{array}{c}\text { Ruas Sisi Kanan } \\
\text { Persamaan Emden- } \\
\text { Fowler }\end{array}$ & $\boldsymbol{m}=\mathbf{2}$ & Galat $\boldsymbol{m}=\mathbf{2}$ & $\boldsymbol{m}=\mathbf{3}$ & Galat $\boldsymbol{m}=\mathbf{3}$ \\
\hline 0,1 & 0 & 0,057974 & 0,057974 & $-0,018138$ & 0,018138 \\
\hline 0,2 & 0 & 0,049318 & 0,049318 & $-0,002412$ & 0,002412 \\
\hline 0,3 & 0 & 0,03489 & 0,03489 & 0,00703 & 0,00703 \\
\hline 0,4 & 0 & 0,014692 & 0,014692 & 0,010599 & 0,010599 \\
\hline 0,5 & 0 & $-0,011277$ & 0,011277 & 0,008751 & 0,008751 \\
\hline 0,6 & 0 & $-0,043018$ & 0,043018 & 0,001984 & 0,001984 \\
\hline 0,7 & 0 & $-0,080529$ & 0,080529 & $-0,009177$ & 0,009177 \\
\hline 0,8 & 0 & $-0,123811$ & 0,123811 & $-0,024176$ & 0,024176 \\
\hline 0,9 & 0 & $-0,172864$ & 0,172864 & $-0,042446$ & 0,042446 \\
\hline 1 & 0 & $-0,227688$ & 0,227688 & $-0,063404$ & 0,063404 \\
\hline & & & & & \\
\hline
\end{tabular}

Berdasarkan Tabel 4, diperoleh bahwa galat pada $m=3$ lebih kecil dari $m=2$. Dengan demikian diperoleh solusi persamaan Emden-Fowler $r=0, n=2$ pada Persamaan (26) adalah terdapat pada Persamaan (50). 


\section{KESIMPULAN}

Berdasarkan hasil dan pembahasan, solusi Persamaan Emden Fowler untuk $r=0, n=0$ adalah $y(x)=1-\frac{x^{2}}{6}$. Kemudian untuk Persamaan Emden-Fowler untuk $r=0, n=1$ diperoleh solusi $y(x)=$ $1-0,170449856 x^{2}+0,011555923 x^{3}$. Sedangkan Persamaan Emden-Fowler untuk $r=0, n=2$ memiliki solusi $y(x)=1-0,173417099 x^{2}+0,021489374 x^{3}$. Dengan memvariasikan derajat dari Polinomial Bernstein menggunakan $m=3$ dan $m=2$ diperoleh bahwa galat dengan $m=3$ lebih kecil daripada saat digunakan $m=2$, baik menggunakan matriks operasional integral maupun matriks operasional diferensial dari Polinomial Bernstein.

\section{DAFTAR PUSTAKA}

[1] S.C. Sihombing dan A. Dahlia, "Penyelesaian Persamaan Diferensial Linear Orde Satu dan Dua disertai Nilai Awal dengan menggunakan Metode Runge Kutta Orde Lima Butcher dan Felhberg (RKF45), Jurnal matematika Integratif, vol. 14, no. 1, Mei 2018.

[2] F., Fardinah, "Solusi Persamaan Diferensial Biasa dengan Metode Runge-Kutta Orde Lima", Journal MSA, vol. 5, no. 1, JanJuni 2017.

[3] R., Munir, Metode Numerik, Bandung : Informatika, 2003.

[4] A. M., Wazwaz, "Adomian Decomposition Method for a Reliable Treatment of the Emden-Fowler Equation", Applied Mathematics and Computation, vol. 161, 543-560, 2005

[5] S. A. Yousefi dan M. Behroozifar , "Operational matrices of polinomial bernsteins and their applications", Journal of Systems Science, vol. 46, pp. 709-716, Maret 2010.

[6] A. Isah dan C. Phang, "A collocation Method based on Genocchi operational matrix for solving Emden Fowler Equations", Journal of Physics, vol. :1-9, 2020

[7] R. Singh, V. Guleria, dan M. Singh, "Haar wavelet Quasilinearization Method for Numerical Solution of Emden Fowler type Equations", Mathematics and Coomputers in Simulation, vol. 174, 123-13, 2020

[8] R.K.M. Pandey dan N. Kumar, "Solution of lane-emden type equations using bernstein operational matrix of differentiation", New Astronomy, vol. 17, pp. 303-308, September 2011.

[9] M. Panjaitan, "Pemahaman Metode Numerik Menggunakan Pemograman Matlab", JurTI, vol. 1, no.1 : 89-94, Juli 2017

[10] A. Saadatmandi, "Bernstein operational matrix of fractional derivatives and its applications", Applied Mathematical Modelling, vol. 38, no. : 1365-1372, August 2013

[11] I. L. Freire, P. L. da Silva dan M. Torrisi, "Lie and noether symmetries for a class of fouth-order Emden-Fowler equations", Journal of Physics A: Mathematical and Theoretical, vol. 46, no. 24, Juni 2013.

[12] G.E. Chatzarakis, S.R. Grace, I. Jadlovska dll., "Oscillation criteria for third-order Emden-Fowler differential equations with unbounded neutral coefficients", Hindawi Complexity, vol. 2019, Agustus 2019.

[13] B. Ibis, "Approximate analytical solutions for nonlinear Emden-Fowler type equations by differential transform method", arXiv preprint arXiv: 1211.3521, 2012.

[14] A. Kalamajska dan K. Mazowiecka, "Some regularity results to the generalized Emden-Fowler equation with irreguler data", Math.Methods Appl.Sci., vol. 38, no. 12, hal. 2479-2495, Juni 2015.

[15] P. Guha, "Generalized Emden-Fowler equation in noncentral curl forces and first integrals", Acta Mechanica, vol. 231, no. 2, hal. 815-825, Februari 2020.

[16] A.S. Bataineh, O. R. Isik, A.K. Alomari dll, "An efficient scheme for time-dependent Emden-Fowler type equations based on two-dimensional Bernstein polynomials", Mathematics, vol. 8,no. 9, 1473, September 2020. 